\title{
Relationship between Menopausal Sweating and Body Mass Index
}

\author{
Emmanuel Amabebe ${ }^{*}$, Sonia I. Osayande ${ }^{2}$, Janet 0. Ozoene ${ }^{2}$, Andrew C. Ugwu ${ }^{2}$ \\ ${ }^{1}$ Department of Physiology, Niger Delta University, Bayelsa, Nigeria \\ ${ }^{2}$ Department of Physiology, University of Benin, Benin City, Nigeria \\ Email: ${ }^{*}$ emmanuelamabebe@yahoo.com
}

Received 10 February 2014; revised 10 March 2014; accepted 30 March 2014

Copyright (C) 2014 by authors and Scientific Research Publishing Inc.

This work is licensed under the Creative Commons Attribution International License (CC BY). http://creativecommons.org/licenses/by/4.0/

(c) $\underset{\mathrm{EY}}{\mathrm{i}}$ Open Access

\section{Abstract}

We sought to examine the relationship between BMI, sweat rate (SR) and sweat volume (SV) in pre-, peri- and postmenopausal women during a moderate exercise. Based on their ages and menstrual cycle history, thirty healthy women were divided into three groups: pre- $(22.5 \pm 0.8 \mathrm{yrs}, \mathrm{n}=$ 10), peri- (46.5 $\pm 1.1 \mathrm{yrs}, \mathrm{n}=10)$ and post- $(52.2 \pm 0.9 \mathrm{yrs}, \mathrm{n}=10)$. Participants underwent a 15minute walk on a treadmill at a constant speed of $4.2 \mathrm{~km} / \mathrm{h}$ at $27^{\circ} \mathrm{C}$. Sweat was collected and measured with a suction apparatus around a confined area of $120 \mathrm{~cm}^{2}$ outlined on the skin of the face and neck of the participants during the exercise. SR and BMI were determined using the formulae: volume of sweat collected exercise time and $\frac{\mathrm{WT}, \mathrm{kg}}{\mathrm{HT}, \mathrm{m}^{2}}$, respectively. The older women had a significantly higher BMI: pre-, peri- and post- $\left(23.7 \pm 1.3 \mathrm{~kg} / \mathrm{m}^{2}\right.$ vs $28.0 \pm 1.2 \mathrm{~kg} / \mathrm{m}^{2}$ vs $\left.28.4 \pm 0.7\right)(\mathrm{p}<0.05)$. Although there was no significant difference in SV $(1.3 \pm 0.4 \mathrm{ml}$ vs $1.7 \pm 0.2 \mathrm{ml}$ vs $0.9 \pm 0.1 \mathrm{ml})$ between the groups, the peri-women showed a significantly higher $S R(0.07 \pm 0.02 \mathrm{ml} / \mathrm{min}$ vs $0.12 \pm 0.01 \mathrm{ml} / \mathrm{min}$ vs $0.06 \pm 0.01 \mathrm{ml} / \mathrm{min})(\mathrm{p}<0.05)$. A significant and positive correlation existed between BMI and SR ( $p<0.05)$; SV ( $<$ <.01). Our findings support the conclusions that increased menopausal sweating is associated with weight gain/increased BMI especially during the perimenopausal transition period.

\section{Keywords}

BMI, Sweating, Menopause, Exercise

\section{Introduction}

Menopause refers to the complete stoppage of menstruation of $\geq 12$ months after the final menstrual cycle. It is

*Corresponding author.

How to cite this paper: Amabebe, E., Osayande, S.I., Ozoene, J.O. and Ugwu, A.C. (2014) Relationship between Menopausal Sweating and Body Mass Index. Open Journal of Endocrine and Metabolic Diseases, 4, 137-146. 
indicated by the absence of ovarian follicular function and a decline in estrogen secretion by the ovaries [1]. It is associated with a variety of symptoms including: hot flushes, night sweats, weight gain, vaginal dryness, sexual dysfunction, decreased libido and sleep disturbance [2]-[5]. Others include: depression, anxiety, fatigue, memory loss, headache, joint pain, bone loss, urogenital atrophy, urinary tract infections and incontinence, increased cardiovascular risk, somatic symptoms and loss of elasticity [4] [6].

The onset of menopause varies between 40 - 50 years with a mean age of 51.4 years [7] [8]. Of the menopausal symptoms, the most common ones are the vasomotor symptoms (VMS) i.e. hot flushes and night sweats [9]-[11] and these are the symptoms for which women seek treatment most often during menopause [12]. Up to $80 \%$ of women experience the classic menopausal VMS [13], and even higher in perimenopausal women [14]-[16]. These symptoms which are capable of disrupting a woman's overall quality of life [17] [18], have been linked to several risk factors such as age, race/ethnicity, education and social class, alcohol use, low estrogen levels, menopausal status, use of hormone replacement therapy, chronic disease status, perceived stress, poor consumption of dairy products, physical activity and BMI [19]-[25].

Weight gain and change in overall body shape are a foremost menopausal symptom with about $90 \%$ of menopausal women gaining some weight in their middle-age (35 - 55 years). Again this commences during perimenopause - the transition years preceding menopause marked with significant hormonal fluctuation. Ageing and life style factors are also implicated [26].

A positive relationship exists between high BMI (increased adiposity) and endogenous estrogen levels. It has been reported that women with high BMI have higher estrogen levels compared to women with low BMI. This is attributed to the increased peripheral aromatization of estrone and conversion of androgens to estrogens by adipocytes [27]-[31]. Hence, weight gain could be protective against menopausal symptoms since the severity of the VMS is associated with a decline in estrogen levels [27] [32] [33]. This hypothesis was true among postmenopausal women but there are suggestions that these associations may differ among perimenopausal women [19].

Antithetical to the above assertions, more reports have shown that increased BMI is a potential risk factor for menopausal VMS. High BMI (overweight and obesity) is positively associated with an increased risk of hot flushes among women in the menopausal transition stage [18] [34]-[36] as women with normal BMI reported better health related quality of life and less hot flushes and night sweats than heavier women [37]. For instance, den Tonkelaar et al. [34] showed that women with a BMI $>25 \mathrm{~kg} / \mathrm{m}^{2}$ were approximately 2 times more likely to experience VMS compared to those with a BMI $\leq 22 \mathrm{~kg} / \mathrm{m}^{2}$. Gallicchio et al. [19] and Schilling et al. [38], found a significantly lower estrogen level in obese women (BMI $\geq 35 \mathrm{~kg} / \mathrm{m}^{2}$ and $>30 \mathrm{~kg} / \mathrm{m}^{2}$, respectively) compared with their normal weight counterparts (BMI $<25 \mathrm{~kg} / \mathrm{m}^{2}$ ) in midlife and hence, a greater risk of experiencing any or more severe hot flushes and night sweats. This could be due to premature onset of ovarian insufficiency [39]. Premenopausal obese women have lower estradiol levels and early onset of hot flushes, but higher estradiol levels postmenopause compared to non-obese women [40]-[42]. Another mechanism involved in the BMI associated increase in hot flushes is that overweight and obese women have more body fat with the attendant insulation preventing heat loss and resulting in an increase in core body temperature and hence high levels of VMS [31] [43]-[45]. Also, the thermoneutral zone of obese women tends to be narrowed predisposing them to increased sweating [35] [46] [47]. The thermoregulatory dysfunction in obese women could also be due to alterations in leptin levels [38] [48]. Leptin decreases the formation of estrogen from circulating androgen precursors and causes thermodysregulation [38] [48] [49], by increasing core body temperature [50]. Serum leptin levels are increased in obese middle-age women and are associated with the occurrence and duration of hot flushes.

Other explanations are that obesity is linked to hot flushes through a decrease in androstendione, dehydroxyepiandrosterone sulphate (DHEA-S) [23], estradiol, estrone, progesterone [19] [38] and sex hormone binding globulin (SHBG) [23] [38].

Given the contrasting views regarding the relationship between body weight/BMI and menopausal sweating, it is pertinent to further investigate this association in women across various reproductive or menopausal stages. Therefore, we sought to examine the relationship between body mass index (BMI), sweat rate (SR) and sweat volume (SV) in premenopausal (pre-), perimenopausal (peri-) and postmenopausal (post-) women during a moderate exercise. We hypothesize that increased BMI/weight gain is related to increase menopausal sweating which could be more pronounced during the perimenopausal transition stage. 


\section{Materials and Methods}

\subsection{Subject Selection}

Approval for this study was obtained from the University of Benin ethical committee. An informed consent was obtained from each participant prior to recruitment. Based on their ages and menstrual cycle history, thirty healthy women were divided into three groups: premenopausal $(n=10)$, perimenopausal $(n=10)$ and postmenopausal $(n=10)$. Women with age $\geq 50$ years who had not menstruated for more than 12 months were classified as postmenopausal; women between the ages of 40 - 50 years with regular or fluctuating menstrual cycles were placed in the perimenopausal group; while those between the ages of 18 - 39 years with regular menstrual cycles were grouped as premenopausal. None of these women was a competitive athlete nor involved in any regular exercise prior to the experiment. Pregnant women, contraceptive users, hormone therapy users, smokers, diabetics, hypertensives and musculoskeletal disease patients were excluded.

All experimental procedures were conducted in the early hours of the day (8 - $10 \mathrm{am})$. This was done to recruit participants in their basal body temperature and hydration status. They had no prior knowledge of the level of exercise they were to undergo and were instructed not to engage in any form of physical exercise on the morning of the experiment. This was in order to standardize their prehydration status. In our previous study, the thirst perception ratings of all participants were reported [51].

\subsection{Experimental Procedure}

Participants were allowed to acclimatize to the laboratory conditions for about 30 minutes. During this period their medical and menstrual histories were obtained for subject recruitment. Height and body weight were measured with the aid of a meter rule and digital weighing scale respectively. From these parameters, the BMI of each participant was calculated with the formula [52]:

$$
\mathrm{BMI}=\frac{\mathrm{WT}, \mathrm{kg}}{\mathrm{HT}, \mathrm{m}^{2}}
$$

Participants' peripheral body temperature was measured from the axilla using mercuryin glass thermometer before the exercise, while the room temperature was obtained using a white wall $215 \mathrm{~mm}$ thermometer. Blood pressures and pulse rate were also measured.

\subsection{Exercise Protocol}

A suitable and convenient moderate exercise protocol was designed for the study. Participants underwent a 15 minute walk on a treadmill calibrated with the Bruce Treadmill protocol [53] at a constant speed of $4.2 \mathrm{~km} / \mathrm{h}$ at $27^{\circ} \mathrm{C}$. This design was also used in our previous studies [51].

\subsection{Sweat Collection}

Sweat was collected with a sweat suction apparatus around a confined area of $120 \mathrm{~cm}^{2}$ outlined on the skin of the face and neck of the participants during the exercise [54]. The volume of sweat collected (SV) was measured and the rate of sweat secretion (SR) calculated using the formula [55]-[57]:

$$
\mathrm{SR}=\frac{\text { volume of sweat collected }}{\text { exercise time }}
$$

The samples were then stored in a collection bottle at $-4^{\circ} \mathrm{C}$.

\subsection{Data Analysis}

Data were analysed using Graphpad Prism 5 statistics software. The student's t-test and one way ANOVA were performed to determine differences in skin temperature, SR, SV and BMI. Possible correlations between BMI, SR and SV were determined by linear regression plots and correlation. p-values $\leq 0.05$ were deemed statistically significant. 


\section{Results}

As expected the peri- and postmenopausal women had a significantly higher BMI $(\mathrm{p}<0.05)$ compared to the premenopausal women (Figure 1).

As reported in our previous study [51], the perimenopausal women exhibited a statistically significant higher SR than women in the other groups $(\mathrm{p}<0.05)$. However, there was no statistically significant difference in the SV between the groups, even though the postmenopausal women had the lowest values.

Linear regression plots revealed a statistically significant and positive correlation between BMI, SR and SV as shown in Figure 2(a) and Figure 2(b), respectively. SR and SV are interdependent, hence a perfect correlation between both (not shown).These data show that there is a concomitant increase in SR and SV with an increase in BMI with other confounding factors closely regulated. In addition, the peri- and postmenopausal women also reported history of discomforting hot flushes and night sweats which had necessitated previous visits to the hospital and some lifestyle modifications.

\section{Discussion}

The relationship between BMI and menopausal VMS has been investigated by several researchers. The hypothesis that high BMI is positively associated with the occurrence and severity of hot flushes and night sweats in midlife women has dominated the arguments [19] [20] [23] [35] [58] [59].

In this study, the relationship between BMI, SR and SV in young women (premenopausal) and middle-age women (peri and postmenopausal) (Table 1) was examined. As expected the older (peri and postmenopausal) women had a significantly higher BMI compared with the younger women. BMI increases with age [60]-[64].

Although the differences in SV between the groups were not statistically significant, we observed that the rate of sweat secretion was significantly higher in the perimenopausal women. This observation was also reported in our previous study [51], indicating that this transition stage is crucial in a woman's life. Around this period, it has also been shown that the VMS are more frequent and tend to reach peak values [13] [15] [16] [65] [66]. Women within this stage of menopause have been identified to be at a higher risk of experiencing hot flushes [21]. Though these symptoms may subside [67] [68], which may account for the low SR and SV recorded by the postmenopausal women in our study, some women contend with them for the rest of their lives [66] [69]. The lower SR observed in the postmenopausal women could also be due to dehydration prior to exercise as older people are more prone to dehydration and decreased thirst sensation [70]-[72].

Although the BMI of our study participants ranged from normal to overweight, a significant and positive correlation was observed between BMI and the rate and volume of sweat secreted. Studies involving obese women (i.e. BMI $>30 \mathrm{~kg} / \mathrm{m}^{2}$ ), could reveal a better correlation. Increase in BMI was identified as a risk factor for increased menopausal sweating especially during perimenopause. This is also supported by reports of increased heat (hot flushes) and discomforting night sweats gathered from these women. This confirms existing reports that overweight and obese middle-age women stand a greater chance of experiencing hot flushes and night sweats compared to normal weight women [18] [24] [31] [36] [59] [73] [74]. These studies were cross sectional [31] [75], longitudinal [45] as well as case control in nature.

Changes in body weight are linked to the occurrence and frequency of VMS as weight gain increases the severity of menopausal sweating and weight loss decreases it [20] [24] [76] [77]. Many explanations ranging from the insulator action of adipose tissue, hormonal disequilibrium, narrow thermoneutral zone and high leptin and $\mathrm{TNF}-\alpha$ concentration, have been postulated.

None of our study participants was a trained athlete nor involved in any regular physical exercise. This could

Table 1. Participants’ anthropometric data.

\begin{tabular}{ccc}
\hline Subjects & Age, years & Peripheral body temperature (before exercise), ${ }^{\circ} \mathbf{C}$ \\
\hline Pre- $(\mathrm{n}=10)$ & $22.5 \pm 0.8$ & $36.9 \pm 0.2$ \\
Peri- $(\mathrm{n}=10)$ & $46.5 \pm 1.1$ & $36.2 \pm 0.1$ \\
Post- $(\mathrm{n}=10)$ & $52.2 \pm 0.9$ & $36.2 \pm 0.2$ \\
\hline
\end{tabular}

Participants' age and peripheral body temperature measured prior to the exercise represented as mean \pm SEM. The body temperature values were within the normal range, a prerequisite for comparison of rate and amount of sweat produced during the exercise. Pre-: Premenopausal; Peri-: Perimenopausal; Post-: Postmenopausal. 


\section{BODY MASS INDEX}

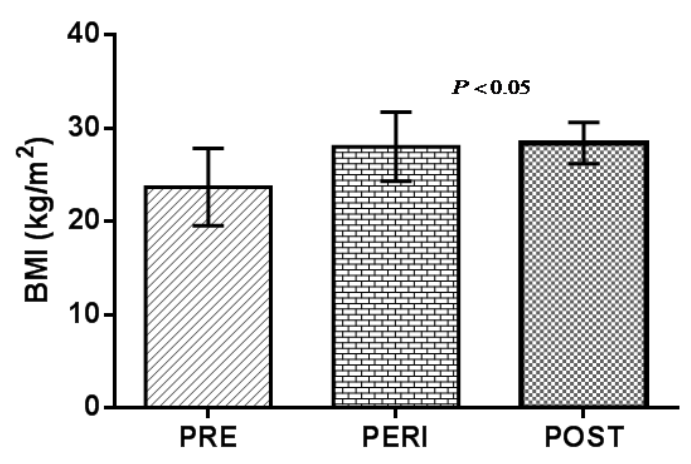

Figure 1. Differences in BMI between the groups. The BMI values of the pre- and postmenopausal women were similar but significantly higher than that of their premenopausal counterparts. $\mathrm{p}<0.05$ statistically significant. The error bars represent the standard error of the mean (SEM).

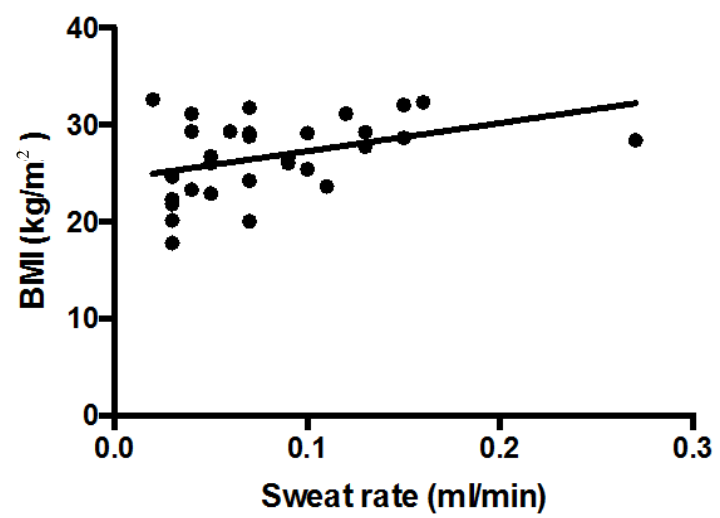

(a)

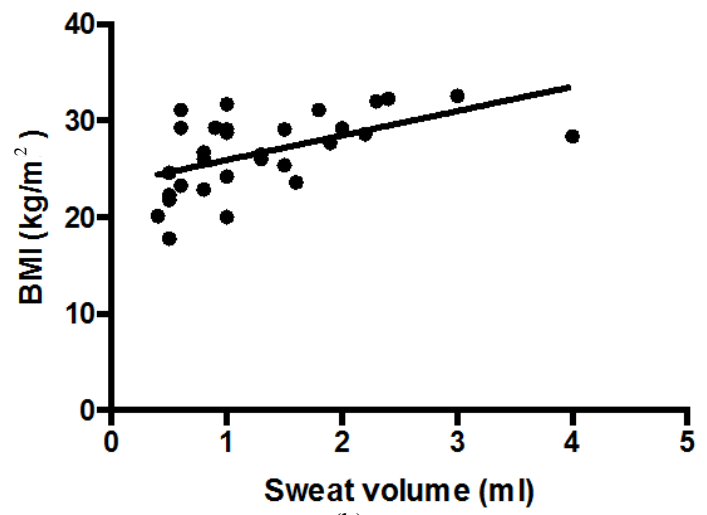

(b)

Figure 2. Relationship between BMI and (a) Sweat rate $(\mathrm{p}<0.05, \mathrm{r}=0.394, \mathrm{Y}=29.01 \mathrm{x}+24.35)$, (b) Sweat volume $(\mathrm{p}<0.01, \mathrm{r}=0.537, \mathrm{Y}=2.536 \mathrm{x}+$ 23.39). Increased sweat rate and volume of sweat produced were associated with high BMI.

also be a contributory factor to our findings. Interestingly, regular physical exercise reduces the risk of not just general symptoms as reported by McAndrew et al. [78], but particularly the frequency of psychological and 
VMS. Sedentary women report more psychological and VMS than physically active women [24], and such active women with severe VMS are fewer than sedentary women [79]. This is because habitual physical exercise stabilizes thermoregulation leading to diminished vasodilatation and sweating [80]. This is achieved through the release of $\beta$-endorphin (opiods) in the hypothalamus or through a decrease in calcitonin gene-related peptide (CGRP). Opiods in the CNS inhibit the synthesis and release of peripheral CGRP [81].

Despite the promising observations recorded in this present study, one weakness identified is our inability to design the exercise protocol in relation to the maximum oxygen consumed or aerobic capacity $\left(\mathrm{VO}_{2}\right.$ max $)$ of each participant. The work load may have been higher for the postmenopausal women considering their age and perhaps a lower aerobic capacity compared to their younger counterparts. Though the Bruce protocol varies speed, participants were subjected to a constant speed on the treadmill in order to maintain the same treatment for each subject. This may have affected the results obtained. Also, there could be the limitation of using one region to represent the whole body sweating. Exploring a combination of other body sites and post-exercise sweating could be outstanding.

\section{Conclusions}

During menopause, the frequency of hot flushes, night sweats and other VMS tends to increase as BMI increases. There is a linear relationship between BMI and rate and amount of sweat secreted during menopause. BMI increases with age. Increase in body weight and sweating (VMS) are critical symptoms of menopause reaching significant (highest) levels at perimenopause. These symptoms may remain throughout the woman's lifetime.

Our findings support the conclusion that increased menopausal sweating is associated with weight gain/high BMI especially during the perimenopausal transition period.

\section{Acknowledgements}

We wish to appreciate the Physiological Society for the opportunity to present part of our findings at the $37^{\text {th }}$ World Congress of the International Union of Physiological Sciences (IUPS), and International Early-Career Symposium held at the ICC and University of Birmingham, Birmingham, UK, respectively, from the $20^{\text {th }}$ $26^{\text {th }}$ July, 2013 (Proc 37th IUPS 2013. PCC247).

\section{Conflict of Interests}

The authors declare that there is no conflict of interest.

\section{References}

[1] Tong, L.I. (2013) Nonpharmacological Treatment of Postmenopausal Symptoms. Obstetrics \& Gynecology, 15, 19-25. http://dx.doi.org/10.1111/j.1744-4667.2012.00143.x

[2] National Institutes of Health State of Science Conference Statement on Management of Menopause-Related Symptoms. (2005) NIH Consensus Development Program. http://consensus.nih.gov/

[3] Nelson, H.D., Haney, E., Humphrey, L., Miller, J., Nedrow, A., Nicolaidis, C., Vesco, K., Walker, M., Bougatsos, C. and Nygren, P.S. (2005) Management of Menopause-Related Symptoms. Evidence Report/Technology Assessment (Summary), 120, 1-6.

[4] Woods, N.F. and Mitchell, E.S. (2005) Symptoms during the Perimenopause: Prevalence, Severity, Trajectory, and Significance in Women's Lives. American Journal of Medicine, 118, S14-24. http://dx.doi.org/10.1016/j.amjmed.2005.09.031

[5] Col, N.F., Guthrie, J.R., Politi, M. and Dennerstein, L. (2009) Duration of Vasomotor Symptoms in Middle-Aged Women: A Longitudinal Study. Menopause, 16, 453-457. http://dx.doi.org/10.1097/gme.0b013e31818d414e

[6] Utian, W.H. (2005) Psychosocial and Socioeconomic Burden of Vasomotor Symptoms in Perimenopause: A Comprehensive Review. Health and Quality of Life Outcomes, 3, 47. http://dx.doi.org/10.1186/1477-7525-3-47

[7] Col, N.F., Fairfield, K.M., Ewan-Whyte, C. and Miller, H. (2009) In the Clinic. Menopause. Annals of Internal Medicine, 150, ITC4-1.

[8] Dratva, J., Real, F.G., Schindler, C., Ackermann-Liebrich, U., Gerbase, M.W., Probst-Hensch, N.M., Svanes, C., Omenaas, E.R., Neukirch, F., Wjst, M., Morabia, A., Jarvis, D., Leynaert, B. and Zemp, E. (2009) Is Age at Menopause Increasing across Europe? Results on Age at Menopause and Determinants from Two Population-Based Studies. 
Menopause, 16, 385-394. http://dx.doi.org/10.1097/gme.0b013e31818aefef

[9] Freedman, R.R. (2001) Physiology of Hot Flashes. American Journal of Human Biology, 13, 453-464. http://dx.doi.org/10.1002/ajhb.1077

[10] Sterns, V., Ullmer, L., Lopez, J.F., Smith, Y., Isaacs, C. and Hayes, D. (2002) Hot Flashes. Lancet, 360, $1851-1861$. http://dx.doi.org/10.1016/S0140-6736(02)11774-0

[11] Miller, R.G. and Ashar, B.H. (2004) Managing Menopause: Current Therapeutic Options for Vasomotor Symptoms. Advanced Studies in Medicine, 4, 484-492.

[12] Deecher, C.D. and Dorries, K. (2007) Understanding the Pathophysiology of Vasomotor Symptoms (Hot Flushes and Night Sweats) That Occur in Perimenopause, Menopause, and Postmenopause Life Stages. Archives of Women's Mental Health, 10, 247-257. http://dx.doi.org/10.1007/s00737-007-0209-5

[13] (2005) National Institutes of Health State of Science Conference Statement on Management of Menopause-Related Symptoms. Annals of Internal Medicine, 142, 1003-1013.

http://dx.doi.org/10.7326/0003-4819-142-12_Part_1-200506210-00117

[14] Leidy, L.E. (1997) Menopausal Symptoms and Everyday Complaints. Menopause, 41, 54-60.

[15] Dennerstein, L., Dudley, E.C., Hopper, J.L., Guthrie, J.R. and Burger, H.G. (2000) A Prospective Population-Based Study of Menopausal Symptoms. Obstetrics \& Gynecology, 96, 351-358. http://dx.doi.org/10.1016/S0029-7844(00)00930-3

[16] Guthrie, J.R., Dennerstein, L., Taffe, J.R. and Donnelly, V. (2003) Health Care-Seeking for Menopausal Problems. Climacteric, 6, 112-117. http://dx.doi.org/10.1080/cmt.6.2.112.117

[17] Hollander, L., Freeman, E.W., Samuel, M.D., Berlin, J.A., Grisso, J.A. and Battistini, M. (2001) Sleep Quality, Estradiol Levels, and Behavioral Factors in Late Reproductive Age Women. Obstetrics \& Gynecology, 98, 391-397. http://dx.doi.org/10.1016/S0029-7844(01)01485-5

[18] Whiteman, M.K., Starpoli, C.A., Langenberg, P.W., McCarter, R.J., Kjerulff, K.H. and Flaws, A.J. (2003) Smoking, Body Mass Index and Hot Flashes in Midlife Women. Obstetrics \& Gynecology, 101, 264-272. http://dx.doi.org/10.1016/S0029-7844(02)02593-0

[19] Gallicchio, L., Visvanathan, K., Miller, R.S., Babus, J., Lewis, M.L., Zacur, H. and Flaws, A.J. (2005) Body Mass Index, Estrogen Levels, and Hot Flashes in Midlife Women. American Journal of Obstetrics \& Gynecology, 193, 13531360. http://dx.doi.org/10.1016/j.ajog.2005.04.001

[20] Greendale, A.G. and Gold, E.B. (2005) Lifestyle Factors: Are They Related to Vasomotor Symptoms and Do They Modify the Effectiveness or Side Effects of Hormone Therapy? American Journal of Medicine, 118, 148S-154S. http://dx.doi.org/10.1016/j.amjmed.2005.09.049

[21] Miller, R.S., Gallicchio, M.L., Lewis, M.L., Babus, J.K., Langenberg, P., Howard, A.Z. and Flaws, A.J. (2006) Association between Race and Hot Flashes in Midlife Women. Maturitas, 54, $260-269$. http://dx.doi.org/10.1016/j.maturitas.2005.12.001

[22] Pérez, A.M.J., Garcia, C.F., Palacios, S. and Pérez, M. (2009) Epidemiolgy of Risk Factors and Symptoms Associated with Menopause in Spanish Women. Maturitas, 62, 30-36. http://dx.doi.org/10.1016/j.maturitas.2008.10.003

[23] Alexander, C., Cochran, C.J., Gallicchio, L., Miller, R.S., Flaws, A.J. and Zacur, H. (2010) Serum Leptin Levels, Hormone Levels, and Hot Flashes in Midlife Women. Fertility and Sterility, 94, 1037-1043. http://dx.doi.org/10.1016/j.fertnstert.2009.04.001

[24] Moilanen, J., Aalto, M.A., Hemminki, E., Aro, R.A., Raitanen, J. and Luoto, R. (2010) Prevalence of Menopause Symptoms and Their Association with Lifestyle among Finnish Middle-Aged Women. Maturitas, 67, 368-374. http://dx.doi.org/10.1016/j.maturitas.2010.08.007

[25] Melby, M.K., Anderson, D., Sievert, L.L. and Obermeyer, C.M. (2011) Methods Used in Cross-Cultural Comparisons of Vasomotor Symptoms and Their Determinants. Maturitas, 70, 110-119. http://dx.doi.org/10.1016/j.maturitas.2011.07.010

[26] Ashiru, O. (2013) Staying Slim at Menopause. Punch. www.Punchng.com/healthwise/staying-slim-at-menopause

[27] Erlik, Y., Meldrum, D.R. and Judd, H.L. (1982) Estrogen Levels in Postmenopausal Women with Hot Flashes. Obstetrics \& Gynecology, 59, 403-407.

[28] Cauley, J.A., Gutal, J.P., Kuller, L.H., DeDonne, D. and Powell, J.G. (1989) The Epidemiology of Serum Sex Hormones in Postmenopausal Women. American Journal of Epidemiology, 129, 1120-1131.

[29] Hankinson, S.E., Willet, W.C., Manson, J.E., Hunter, D.J., Colditz, G.A., Stampfer, M.J., Longcope, C. and Speizer, F.E. (1995) Alcohol, Height, and Adiposity in Relation to Estrogen and Prolactin Levels in Postmenopausal Women. Journal of the National Cancer Institute, 87, 1297-1302. http://dx.doi.org/10.1093/jnci/87.17.1297 
[30] Avis, N.E., Crawford, S.L. and McKinlay, S.M. (1997) Psychosocial, Behavioral, and Health Factors Related to Menopause Symptomatology. Women's Health, 3, 103-120.

[31] Gold, E.B., Sternfeld, B., Kelsey, J.L., Brown, C., Mouton, C., Reame, N., Salamone, L. and Stellato, R. (2000) Relation to Demographic and Lifestyle Factors to Symptoms of Women 40 - 55 Years of Age. American Journal of Epidemiology, 152, 463-473. http://dx.doi.org/10.1093/aje/152.5.463

[32] Wilbur, J., Miller, A.M., Montgomery, A. and Chandler, P. (1998) Sociodemographic Characteristics, Biological Factors, and Symptom Reporting in Midlife Women. Menopause, 5, 43-51. http://dx.doi.org/10.1097/00042192-199805010-00008

[33] Overlie, I., Meon, M.H., Holte, A. and Finset, A. (2002) Androgens and Estrogens in Relation to Hot Flushes during the Menopausal Transition. Maturitas, 41, 69-77. http://dx.doi.org/10.1016/S0378-5122(01)00256-0

[34] den Tonkelaar, I., Seidell, J.C. and van Noord, P.A. (1996) Obesity and Fat Distribution in Relation to Hot Flashes in Dutch Women from the DOM-Project. Maturitas, 23, 301-305. http://dx.doi.org/10.1016/0378-5122(95)00990-6

[35] Freeman, E.W., Sammel, M.D., Grisso, J.A., Battistini, M., Garcia-Espagna, B. and Hollander, L. (2001) Hot Flashes in the Late Reproductive Years: Risk Factors for African American and Caucasian Women. Journal of Women's Health \& Gender-Based Medicine, 10, 67-76. http://dx.doi.org/10.1089/152460901750067133

[36] Hyde, R.E., Inui, T.S., Kleinman, K. and Connelly, M.T. (2004) Differential Association of Modifiable Health Behaviors with Hot Flashes in Perimenopausal and Postmenopausal Women. Journal of General Internal Medicine, 19, 740746. http://dx.doi.org/10.1007/s11606-004-0002-3

[37] Daley, A., MacArthur, C., Stokes-Lampard, H., McManus, R., Wilson, S. and Mutrie, N. (2007) Exercise Participation, Body Mass Index, and Health-Related Quality of Life in Women of Menopausal Age. British Journal of General Practice, 57, 130-135.

[38] Schilling, C., Gallicchio, L. Miller, S.R., Langenberg, P., Zacur, H. and Flaws, J.A. (2007) Relation of Body Mass and Sex Steroid Hormone Levels to Hot Flushes in a Sample of Mid-Life Women. Climacteric, 10, 27-37. http://dx.doi.org/10.1080/13697130601164755

[39] Klinga, K., von Holst, T. and Runnebaum, B. (1983) Influence of Severe Obesity on Peripheral Hormone Concentrations in Pre- and Postmenopausal Women. European Journal of Obstetrics \& Gynecology and Reproductive Biology, 15, 103-112. http://dx.doi.org/10.1016/0028-2243(83)90178-8

[40] Randolph Jr., J.F., Sowers, M., Bondarenko, I.V., Harlow, S.D., Luborsky, J.L. and Little, R.J. (2004) Change in Estradiol and Follicle-Stimulating Hormone across the Early Menopausal Transition: Effects of Ethnicity and Age. The Journal of Clinical Endocrinology Metabolism, 89, 1555-1561. http://dx.doi.org/10.1210/jc.2003-031183

[41] Freeman, E.W., Sammel, M.D., Lin, H. and Garcia, C.R. (2010) Obesity and Reproductive Hormone Levels in the Transition to Menopause. Menopause, 17, 718-726.

[42] Freeman, E.W., Sammel, M.D., Lin, H., Liu, Z. and Garcia, C.R. (2011) Duration of Menopausal Hot Flushes and Associated Risk Factors. Obstetrics \& Gynecology, 117, 1095-1104. http://dx.doi.org/10.1097/AOG.0b013e318214f0de

[43] Glickman-Weiss, E.L., Nelson, A.G., Hearon, C.M., Prisby, R. and Caine, N. (1999) Thermal and Metabolic Responses of Women with High Fat Versus Low Fat Body Composition during Exposure to 5 and 27 Degrees C for 120 min. Aviation, Space and Environmental Medicine, 70, 284-288.

[44] Freedman, R.R. (2005) Pathophysiology and Treatment of Menopausal Hot Flashes. Seminars in Reproductive Medicine, 23, 117-125. http://dx.doi.org/10.1055/s-2005-869479

[45] Thurston, R., Sowers, M., Chang, Y., Sternfeld, B., Gold, E., Jonston, J. and Matthews, A. (2008) Adiposity and Reporting of Vasomotor Symptoms among Midlife Women: The Study of Women's Health across the Nation. American Journal of Epidemiology, 167, 78-85. http://dx.doi.org/10.1093/aje/kwm244

[46] Leon, L.R., White, A.A. and Kluger, M.J. (1998) Role of IL-6 and TNF in Thermoregulation and Survival during Sepsis in Mice. American Journal of Physiology, 275, 269-277.

[47] Freedman, R.R. (2002) Hot Flash Trends and Mechanisms. Menopause, 9, 151-152. http://dx.doi.org/10.1097/00042192-200205000-00001

[48] Casper, R.F. and Yen, S.S. (1985) Neuroendocrinology of Menopausal Flushes: A Hypothesis of Flush Mechanism. Clinical Endocrinology, 22, 293-312. http://dx.doi.org/10.1111/j.1365-2265.1985.tb03243.x

[49] Anderson, G.S. (1999) Human Morphology and Temperature Regulation. International Journal of Biometeorology, 43, 99-109. http://dx.doi.org/10.1007/s004840050123

[50] Luheshi, G., Gardner, J., Rushforth, D., Loudon, A. and Rothwell, N. (1999) Leptin Actions on Food Intake and Body Temperature Are Mediated by IL-1. Proceedings of National Academy of Science of the United States of America, 96, 7047-7052. http://dx.doi.org/10.1073/pnas.96.12.7047

[51] Amabebe, E., Omorodion, S.I., Ozoene, J.O., Ugwu, A.C. and Obika, L.F. (2013) Sweating and Thirst Perception in 
Premenopausal, Perimenopausal and Postmenopausal Women during Moderate Exercise. Journal of Experimental and Integrative Medicine, 3, 279-284. http://dx.doi.org/10.5455/jeim.280813.or.087

[52] WHO (2000) Obesity: Preventing and Managing the Global Epidemic. Report of WHO Consultation, WHO Technical Report Series 894, World Health Organisation, Geneva.

[53] Bruce, R.A., Blackman, J.R., Jones, J.W. and Straty, G. (1963) Exercise Testing in Adult Normal Subjects and Cardiac Patients. Pediatrics, 32, 742.

[54] Ugwu, A.C. and Oyebola, D.D.O. (1996) Sweat Collection Made Easy. Journal of Medical Laboratory Science, 5, 171-176.

[55] Ugwu, A.C. (1985) Sex Differences in Sweat Rates and Composition in Human Populations Indigenous to a Tropical Hot and Humid Climate. International Research Communications System, 13, 938-939.

[56] Minkin, M.J., Carol, M.D. and Wright, V. (1997) What Every Woman Needs to Know about Menopause: The Years before, during and after. Yale University Press, New Haven, 261-269.

[57] Beverage Institute for Health and Wellness (Accessed 14 September 2013) How to Calculate Your Sweat Rate? http://beverageinstitute.org/us/article/how-to-calculate-your-sweat-rate

[58] Chiechi, L.M., Ferreri, R., Granieri, M., Bianco, G., Berardesca, C. and Loizzi, P. (1997) Climacteric Syndrome and Body Weight. Clinical and Experimental Obstetrics \& Gynecology, 24, 163-166.

[59] Gold, E.B., Block, G., Crawford, S., Lachance, L., FitzGerald, G., Miracle, H. and Sherman, S. (2004) Lifestyle and Demographic Factors in Relation to Vasomotor Symptoms: Baseline Results from the Study of Women's Health across the Nation. American Journal of Epidemiology, 159, 1189-1199. http://dx.doi.org/10.1093/aje/kwh168

[60] Welon, Z., Szklarska, A., Bielicki, T. and Malina, R.M. (2002) Sex Differences in the Pattern of Age-Dependent Increase in the BMI from 20 - 59 Years. American Journal of Human Biology, 14, 693-698. http://dx.doi.org/10.1002/ajhb.10079

[61] Pasquet, P., Temgoua, L.S., Melaman-Sego, F., Froment, A. and Rikong-Adie, H. (2003) Prevalence of Overweight and Obesity for Urban Adults in Cameroon. Annals of Human Biology, 30, 551-562. http://dx.doi.org/10.1080/0301446032000112652

[62] Reas, D.L., Nygard, J.F., Svensson, E., Sørensen, T. and Sandanger, I. (2007) Changes in Body Mass Index by Gender, and Socio-Economic Status among a Cohort of Norwegian Men and Women (1990-2001). BMC Public Health, 30, 269. http://dx.doi.org/10.1186/1471-2458-7-269

[63] Hall, S.B. and Hanson, J. (2008) Women Body Mass Index Certainly Changes with Age. http://www.halls.md/body-mass-index/womens.htm

[64] Hou, X.H., Jia, W., Bao, Y.Q., Lu, H.J., Jiang, S., Zou, Y.H., Gu, H. L. and Xiang, K.S. (2008) Risk Factors for Overweight and Obesity and Changes in Body Mass Index of Chinese Adults in Shanghai. BMC Public Health, 8, 389. http://dx.doi.org/10.1186/1471-2458-8-389

[65] Feldman, B.M., Voda, A. and Gronseth, E. (1985) The Prevalence of Hot Flash and Associated Variables among Perimenopausal Women. Research in Nursing \& Health, 8, 261-268. http://dx.doi.org/10.1002/nur.4770080308

[66] Rödström, K., Bengtsson, C., Lissner, L., Milsom, I., Sundh, V. and Bjorkelund, C. (2002) A Longitudinal Study of the Treatment of Hot Flashes: The Population Study of Women in Gothenburg during a Quarter of a Century. Menopause, 9, 156-161. http://dx.doi.org/10.1097/00042192-200205000-00003

[67] Guthrie, J.R., Dennerstein, L., Taffe, J.R., Lehert, P. and Burger, H.G. (2004) The Menopausal Transition: A 9-Year Prospective Population-Based Study. The Melbourne Women’s Midlife Health Project. Climacteric, 7, 375-389. http://dx.doi.org/10.1080/13697130400012163

[68] Avis, N.E., Brockwell, S. and Colvin, A. (2005) A Universal Menopausal Syndrome? The American Journal of Medicine, 118, 37-46. http://dx.doi.org/10.1016/j.amjmed.2005.09.057

[69] Kronenberg, F. (1990) Hot Flashes: Epidemiology and Physiology. Annals of the New York Academy Sciences, 592, 52-86. http://dx.doi.org/10.1111/j.1749-6632.1990.tb30316.x

[70] Ferry, M. (2005) Strategies for Ensuring Good Hydration in Elderly. Nutrition Reviews, 63, 22-29. http://dx.doi.org/10.1111/j.1753-4887.2005.tb00151.x

[71] Mentes, J. (2006) Oral Hydration in Older Adults: Greater Awareness Is Needed in Preventing, Recognizing, and Treating Dehydration. American Journal of Nursing, 106, 40-49. http://dx.doi.org/10.1097/00000446-200606000-00023

[72] Millard-Stafford, M., Wendland, D.M., O’Dea, N.K. and Norman, T.L. (2012) Thirst and Hydration Status in Everyday Life. Nutrition Reviews, 70, 147-151. http://dx.doi.org/10.1111/j.1753-4887.2012.00527.x

[73] Schwingl, P.J., Hulka, B.S. and Harlow, S.D. (1994) Risk Factors for Menopausal Hot Flashes. Obstetrics \& Gynecology, 84, 29-34. 
[74] Riley, E., Inui, T., Keinmam, K. and Connelly, M. (2004) Differential Association of Modifiable Health Behaviors with Hot Flashes in Perimenopausal and Postmenopausal Women. Journal of General Internal Medicine, 19, 740-746. http://dx.doi.org/10.1007/s11606-004-0002-3

[75] Ford, K., Sowers, M., Crutchfield, M., Wilson, A. and Jannausch, M. (2005) A Longitudinal Study of the Predictors of Prevalence and Severity of Symptoms Commonly Associated with Menopause. Menopause, 12, 308-317. http://dx.doi.org/10.1097/01.GME.0000163869.89878.D9

[76] van Poppel, M.N. and Brown, W.J. (2008) “Its My Hormones, Doctor”-Does Physical Activity Help with Menopausal Symptoms? Menopause, 15, 78-85.

[77] Thurston, R., Sowers, M.R., Sternfeld, B., et al. (2009) Gains in Body Fat and Vasomotor Symptom Reporting over the Menopausal Transition: The Study of Women's Health across the Nation. American Journal of Epidemiology, 170, 766-774. http://dx.doi.org/10.1093/aje/kwp203

[78] McAndrew, M.L., Napolitano, A.M., Albrecht, A., Farrell, C.N., Marcus, H.B. and Whiteley, A.J. (2009) When, Why and for Whom There Is a Relationship between Physical Activity and Menopause. Maturitas, 64, 119-125.

[79] Mirzaiinjmabadi, K., Anderson, D., Barnes, M. (2006) The Relationship between Exercise, Body Mass Index and Menopausal Symptoms in Midlife Australian Women. International Journal of Nursing Practice, 12, 28-34. http://dx.doi.org/10.1111/j.1440-172X.2006.00547.x

[80] Ivarsson, T., Spetz, A. and Hammar, M. (1998) Physical Exercise and Vasomotor Symptoms in Postmenopausal Women. Maturitas, 29, 139-146. http://dx.doi.org/10.1016/S0378-5122(98)00004-8

[81] Collin, E., Frechilla, D., Phol, M., Bourgoin, S., Le Bars, D., Hammon, M. and Casselin, F. (1993) Opioid Control of the Release of Calcitonin Gene-Related Peptide-Like Material from the Rat Spinal Cord in Vivo. Brain Research, 609, 211-222. http://dx.doi.org/10.1016/0006-8993(93)90875-N 
Scientific Research Publishing (SCIRP) is one of the largest Open Access journal publishers. It is currently publishing more than 200 open access, online, peer-reviewed journals covering a wide range of academic disciplines. SCIRP serves the worldwide academic communities and contributes to the progress and application of science with its publication.

Other selected journals from SCIRP are listed as below. Submit your manuscript to us via either submit@scirp.org or Online Submission Portal.
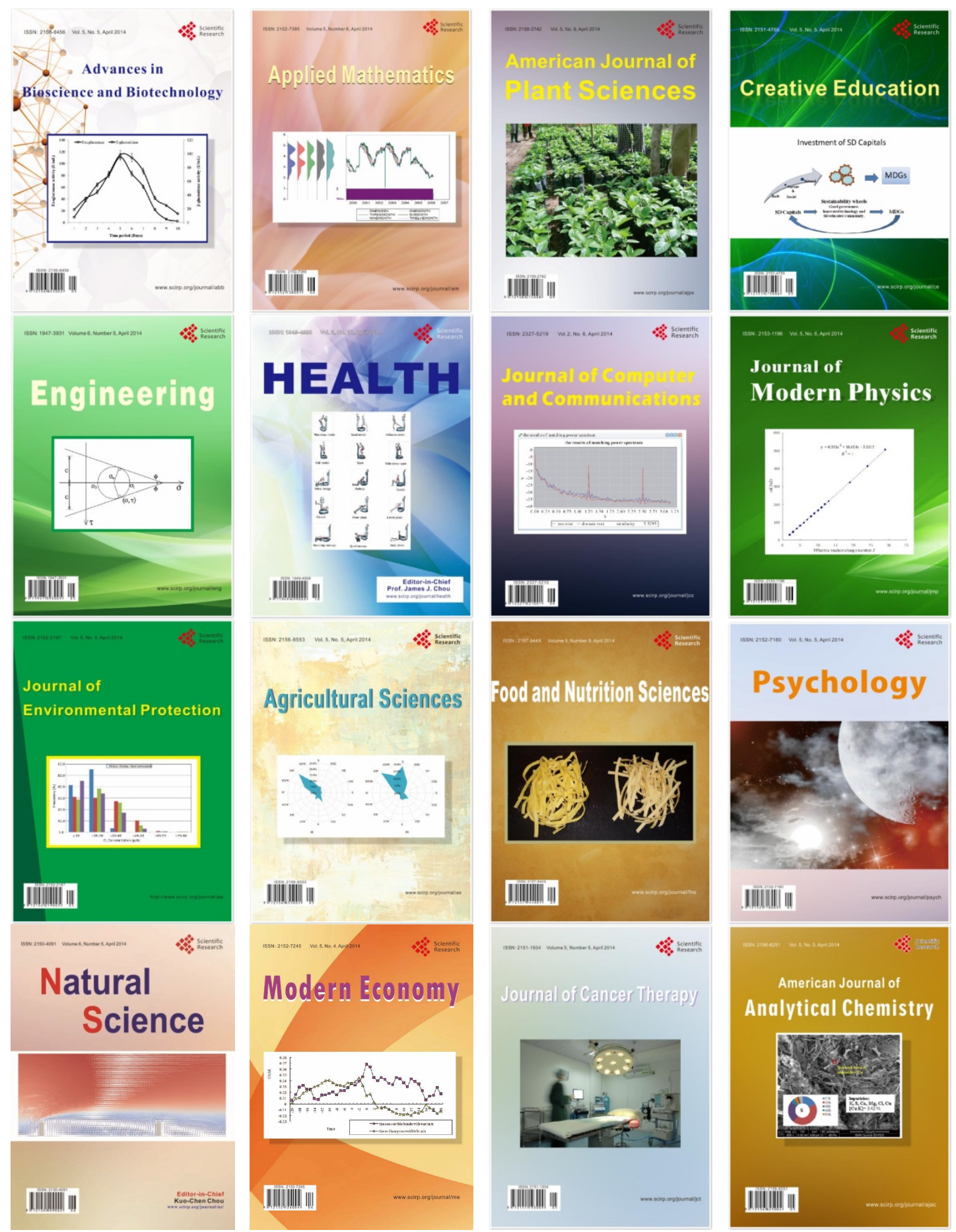